\title{
The utilization of protein as a source of energy in fattening sheep
}

\author{
BY K. L. BLAXTER AND A. K. MARTIN \\ Hannah Dairy Research Institute, Kirkhill, Ayr \\ (Received I4 December 1961-Revised I6 February 1962)
}

Many of the diets given to ruminants contain more protein than is required to meet the protein needs of maintenance and growth. Thus cattle fattening on very highquality pasture receive on occasions nearly five times as much protein as they need as a source of amino acids. In winter, larger amounts of nitrogen are usually given than minimal requirements dictate because the appetite for diets low but adequate in $\mathrm{N}$ content is usually poor. Rations containing an excess of $\mathrm{N}$ are more readily eaten.

The value to be placed on protein as a source of energy for productive purposes is thus of importance in any assessment of the nutritive value of diets. The calorimetric experiments of Kellner \& Köhler (1905) with steers and of Heim (I956) with sheep, showed that when protein supplements were given they were digested to the extent of 86 and $93 \%$, and that for every roo kcal of protein energy given in addition to a maintenance ration 33 and $35 \mathrm{kcal}$ were retained in the body by cattle and sheep respectively. Similar experiments with pigs by Fingerling, Köhler \& Reinhardt (1912-13) and with rats by Kriss, Forbes \& Miller (1934) showed protein supplements to be better digested by these simple-stomached species than by ruminants and that pigs and rats retained respectively 57 and $55 \mathrm{kcal}$ energy/ roo kcal protein energy given. The net availability of the metabolizable energy of protein in the two sets of experiments was 46 and $48 \%$ with cattle and sheep respectively and 74 and $69 \%$ with pigs and rats respectively. Ruminant animals thus produce about $60 \%$ more heat than do non-ruminants when the metabolizable energy of protein is used to synthesize fat.

The experiments reported here, which have already been briefly summarized (Martin \& Blaxter, I96I) were undertaken to find whether the low utilization of protein by ruminants for fat synthesis is contingent upon its fermentation in the rumen or whether it reflects some difference in the way ruminants obtain free energy from the dissimilation of protein when they are compared with species with simple stomachs.

\section{EXPERIMENTAL}

Animals. Two sheep (B and P) were fitted with cannulas into the rumen and two ( $\mathrm{E}$ and $\mathrm{F}$ ) with cannulas into the abomasum. The abomasal cannulas were inserted $2 \mathrm{~cm}$ distant from the pylorus in each sheep. The sheep were of mixed breeding and weighed between 63 and $72 \mathrm{~kg}$.

Food. Each sheep was given a constant ration of artificially dried grass containing either 2.09 or $2.20 \% \mathrm{~N}$ on a dry basis in the amounts given in Table $\mathrm{I}$ throughout 
the experiment. The ration was calculated to provide sufficient energy to allow some gain of energy by the body, and to supply an excess of $\mathrm{N}$. The $\mathrm{N}$ supplied by this basal ration was estimated to be twice the animal's minimal need.

Treatment. Each sheep was confined in a respiration chamber and was given its standard ration. At the same time either $21 . / 24 \mathrm{~h}$ of a dilute salt solution containing $6 \mathrm{~g} \mathrm{NaCl}, 0.4 \mathrm{~g} \mathrm{KCl}, 0.2 \mathrm{~g} \mathrm{MgCl}_{2}, 0.2 \mathrm{~g} \mathrm{CaCl}$ and $0.45 \mathrm{~g} \mathrm{NaH}_{2} \mathrm{PO}_{4} .2 \mathrm{H}_{2} \mathrm{O}$ per 1 . (Armstrong \& Blaxter, 1957) or a solution of casein in this saline was infused into the gut. When more than $17 \mathrm{~g}$ casein were given daily the volume of the infusion was increased to $31 . / 24 \mathrm{~h}$. All infusions continued for at least 7 days. The periods when infusions of saline were given are termed control periods and were repeated at intervals, three to four determinations being made with each animal. To sheep B and $P$, which were fitted with rumen cannulas, casein was given on two and four occasions respectively. Sheep $\mathrm{F}$ and $\mathrm{E}$ which were fitted with abomasal cannulas were each given casein on three occasions. Six sets of observations with casein were thus made with each type of preparation. The amount of casein varied from $\mathrm{I}_{5}$ to $3 \mathrm{I} \mathrm{g} \mathrm{N}$ for the sheep with rumen cannulas and from I I to $26 \mathrm{~g} \mathrm{~N}$ for those given it by abomasal infusion. In any one 7-day period the amount given each day was constant.

Casein. The casein used was a commercial preparation, Casumen (C. and G. Prideaux Ltd, Evercreech, Somerset). It was an acid, light casein which dissolved in saline to give an opalescent solution with a grey tinge. Its $\mathrm{N}$ content on a dry basis was $14 \cdot 8-14 \cdot 9 \%$ and on a dry, ash-free basis it was $15-15 \cdot 6 \%$. Its calorific value on a dry, ash-free basis varied from 5.985 to $5.992 \mathrm{kcal} / \mathrm{g}$ in different batches.

Calorimetric methods. The apparatus used to determine $\mathrm{O}_{2}$ consumption and $\mathrm{CO}_{2}$ and $\mathrm{CH}_{4}$ production was that of Wainman \& Blaxter (1958) and the general technique was similar to that described by Armstrong \& Blaxter (1957). Metabolism of C, N and energy was measured on 5 consecutive days in each period, and computations of the energy retained were made both from the $\mathrm{C}$ and $\mathrm{N}$ retentions and from calorimetric determinations on food and excreta and heat production calculated from the respiratory exchange. Urine was collected by aspiration into dilute acid. The small pump used sucked air continuously through a urine funnel attached to the sheep. Any volatile ammonia in this air stream was collected in pumice moistened with conc. sulphuric acid.

Chemical methods. The methods for determination of $\mathrm{C}, \mathrm{N}$ and calorific values in food and excreta were those of Graham, Armstrong \& Blaxter (1958). Analyses of urine were made daily. Faeces were pooled for 6 days and samples of the pooled faeces were analysed. Analyses of foods were made on samples taken when the rations for the whole experiment were weighed. In urine, ammonia and urea were estimated by the methods of Van Slyke \& Cullen (1914), creatine and creatinine by the Jaffe reaction (Bonsnes \& Taussky, 1945), hippuric acid by the method of Hampton (1948) and allantoin by the method of Young \& Conway (1942).

In blood, ammonia was determined by Conway's (1947) micro-diffusion method and urea by the urease method of Van Slyke \& Cullen (1914). 


\section{RESULTS}

Utilization of the basal ration. Table I summarizes the results of measurements of the $\mathrm{N}$ and energy metabolism of the sheep when the basal ration was given. The results are the mean for four experiments each lasting 5 days for sheep $\mathrm{B}, \mathrm{F}$ and $\mathrm{E}$, but of two only for sheep P. During the final control period of the experiment with this sheep, heat production, methane production and the amount of urinary $\mathrm{N}$ were markedly increased over initial values. No explanation for this change in metabolism was found, but an infection was suspected.

All the sheep digested the $\mathrm{N}$ of the basal ration equally well, and the metabolizability of the gross energy of the rations was the same in them all. Both $\mathrm{N}$ retention and energy retention were positive in all the sheep, some variation being apparent from sheep to sheep. The conditions for measuring the utilization of protein as a source of energy were, therefore, met. The sheep were all storing energy and protein and the high urinary $\mathrm{N}$ showed that amino acids were being absorbed from the diet in excess of bodily needs for synthesis of protein.

Table 1. Nitrogen and energy metabolism of the fattening sheep when the basal ration was given

\begin{tabular}{|c|c|c|c|c|}
\hline & \multicolumn{4}{|c|}{ Sheep } \\
\hline & \multicolumn{2}{|c|}{ With rumen cannulas } & \multicolumn{2}{|c|}{ With abomasal cannulas } \\
\hline & B & $\mathbf{P}$ & $\mathrm{F}$ & $\mathrm{E}$ \\
\hline Dry-matter intake (g/day) & $8 \mathrm{I} 7$ & 890 & $8 \times 7$ & $8 \mathrm{I} 7$ \\
\hline \multicolumn{5}{|c|}{ Nitrogen metabolism } \\
\hline $\begin{array}{l}\mathrm{N} \text { intake }(\mathrm{g} / \text { day) } \\
\mathrm{N} \text { apparently digested }(\%) \\
\text { Urinary } \mathrm{N}(\mathrm{g} / \text { day) } \\
\mathrm{N} \text { retained }(\mathrm{g} / \text { day })\end{array}$ & $\begin{array}{r}17 \cdot 99 \\
60 \cdot 7 \\
8 \cdot 92 \\
+2 \cdot 00\end{array}$ & $\begin{array}{r}18 \cdot 56 \\
58 \cdot 7 \\
7 \cdot 69 \\
+3 \cdot 20\end{array}$ & $\begin{array}{l}\text { I } 7 \cdot 99 \\
58 \cdot 1 \\
10 \cdot 00 \\
+0 \cdot 45\end{array}$ & $\begin{array}{l}17 \cdot 99 \\
59 \cdot 0 \\
9 \cdot 55 \\
+1 \cdot 06\end{array}$ \\
\hline \multicolumn{5}{|c|}{ Energy metabolism } \\
\hline $\begin{array}{l}\text { Energy intake (kcal/day) } \\
\text { Methane production (kcal/roo kcal } \\
\text { energy intake) }\end{array}$ & $\begin{array}{l}3699 \\
5 \cdot 84\end{array}$ & $\begin{array}{l}4011 \\
6.03\end{array}$ & $\begin{array}{l}3699 \\
6.09\end{array}$ & $\begin{array}{l}3699 \\
6 \cdot 50\end{array}$ \\
\hline Metabolizable energy (kcal/day) & 1932 & 2068 & I907 & I 927 \\
\hline $\begin{array}{l}\text { Metabolizable energy }(\mathrm{kcal} / \mathrm{1} 00 \mathrm{kcal} \\
\text { energy intake) }\end{array}$ & $52 \cdot 2$ & $5 I \cdot 6$ & $5 I \cdot 5$ & $52 \cdot 1$ \\
\hline \multicolumn{5}{|l|}{ Energy retained (kcal/day): } \\
\hline From heat measurements & +357 & +89 & +233 & +108 \\
\hline $\begin{array}{l}\text { From } \mathrm{C} \text { and } \mathrm{N} \text { retention } \\
\text { Mean }\end{array}$ & $\begin{array}{l}+380 \\
+368\end{array}$ & $\begin{array}{l}+94 \\
+92\end{array}$ & $\begin{array}{l}+199 \\
+216\end{array}$ & $\begin{array}{l}+\quad 4 \\
+\quad 56\end{array}$ \\
\hline No of 5-day observations & 4 & 2 & 4 & 4 \\
\hline
\end{tabular}

Apparent digestibility of the casein supplements. The apparent digestibility of the casein supplements was assessed from measurements of the increases above control periods in the amounts of $\mathrm{N}, \mathrm{C}$ and energy excreted in the faeces when casein was infused. The mean results are given in Table 2. The value obtained for the faecal $\mathrm{N}$ excretion of sheep $B$ when $23.3 \mathrm{~g}$ casein $\mathrm{N}$ were infused was clearly in error and this value was omitted when the mean was calculated. The mean values show that $\mathrm{N}$ 
given by abomasal infusion did not increase the output of faecal $\mathrm{N}$ whereas that given by rumen infusion did, some $6 \%$ appearing in the faeces. The odds that the apparent digestibility in this instance was not $100 \%$ were $\mathrm{I} 2: \mathrm{I}$.

Measurements of the apparent digestibility of the energy of the casein supplements showed that, when they were given by infusion into the rumen, $90 \cdot 1 \pm 6 \cdot \mathrm{I} \mathrm{kcal} / \mathrm{I}$ oo kcal casein were apparently digested. When casein was given by abomasal infusion, the mean value was $99 \cdot 7 \pm 5 \cdot 8 \mathrm{kcal} / \mathrm{ro0} \mathrm{kcal}$ casein. These coefficients of apparent digestibility for the energy of the casein do not differ significantly from those for the $\mathrm{N}$ of the casein and again indicate that when given by infusion into the rumen casein was absorbed less completely than when given by abomasal infusion.

Table 2. Apparent digestibility of the nitrogen of casein supplements given to fattening sheep by infusion into the rumen or abomasum

\begin{tabular}{|c|c|c|c|}
\hline Route of infusion & Sheep & $\begin{array}{l}\text { Casein N } \\
\text { infused } \\
(\mathrm{g})\end{array}$ & $\begin{array}{c}\text { Apparent } \\
\text { digestibility } \\
\text { of } N \\
(\%)\end{array}$ \\
\hline \multirow[t]{3}{*}{ Rumen } & B & $\begin{array}{l}15 \cdot 4 \\
23 \cdot 2\end{array}$ & $\begin{array}{c}94 \cdot 8 \\
(82 \cdot 6)^{*}\end{array}$ \\
\hline & $\mathrm{P}$ & $\begin{array}{l}16 \cdot 3 \\
16 \cdot 2 \\
26 \cdot 7 \\
30 \cdot 8\end{array}$ & $\begin{array}{l}93 \cdot 8 \\
93 \cdot 2 \\
93 \cdot 9 \\
92 \cdot 3\end{array}$ \\
\hline & Mean & - & $93 \cdot 6 \pm 2 \cdot 7 \dagger$ \\
\hline \multirow[t]{3}{*}{ Abomasum } & $\mathrm{F}$ & $\begin{array}{l}13.6 \\
15.0 \\
25.7\end{array}$ & $\begin{array}{l}96 \cdot \mathbf{I} \\
99 \cdot 8 \\
99 \cdot 2\end{array}$ \\
\hline & $\mathrm{E}$ & $\begin{array}{l}12 \cdot 6 \\
11 \cdot 1 \\
14 \cdot 2\end{array}$ & $\begin{array}{r}100 \cdot 2 \\
103.7 \\
99.7\end{array}$ \\
\hline & Mean & - & $99 \cdot 8 \pm 2.5 \dagger$ \\
\hline
\end{tabular}

Methane production. The increases in methane production observed when casein was infused are summarized in Table 3 . When casein was infused into the abomasum there were slight increases in methane production in some experiments and slight falls in others. The mean value of $0.6 \pm 0.92 \mathrm{kcal} \mathrm{CH}_{4} / 100 \mathrm{kcal}$ casein given indicates no significant fermentation of the supplement. When casein was given by infusion into the rumen, however, methane production increased by $7.63 \pm \mathrm{I} \cdot \mathrm{I} 6 \mathrm{kcal} \mathrm{CH}_{4} /$ I00 kcal casein given. As can be seen by comparison with the results shown in Table I, this value did not differ significantly from the mean rate of methane production from the basal ration, namely $6.12 \pm 0.17 \mathrm{kcal} \mathrm{CH}_{4} / 100 \mathrm{kcal}$. It appears, therefore, that casein given by infusion into the rumen resulted in an increase in the fermentative loss of methane.

Excretion of $N, C$ and energy in urine. The percentage of the $\mathrm{N}$ of the supplementary casein that appeared in urine was calculated from the increases in the $\mathrm{N}$ content of urine above those found when the basal ration was given. The results are summarized 
in Table 4 , and they show that $83 \%$ of the casein $\mathrm{N}$ given was excreted in the urine of the sheep given casein by rumenal infusion and $86 \%$ by the sheep given it by abomasal infusion, the difference not being significant. The number of calories excreted in the urine when casein was infused into the rumen was, however, greater than when casein was infused into the abomasum, as shown by the higher incremental ratios of energy to $\mathrm{N}$ in the last column of Table 4 . The increases in the calorific value of the

Table 3. Increases in methane production of sheep given casein supplements by infusion into the rumen or abomasum

\begin{tabular}{|c|c|c|c|c|}
\hline \multirow[b]{2}{*}{ Route of infusion } & \multirow[b]{2}{*}{ Sheep } & \multirow[b]{2}{*}{$\begin{array}{l}\text { Casein N } \\
\text { supplied } \\
\text { (g) }\end{array}$} & \multicolumn{2}{|c|}{$\begin{array}{l}\text { Increase }(+) \text { or decrease } \\
(-) \text { in methane production }\end{array}$} \\
\hline & & & $\mathrm{kcal} / \mathrm{day}$ & $\begin{array}{l}\mathrm{kcal} / \text { roo kcal } \\
\text { casein }\end{array}$ \\
\hline Rumen & B & $\begin{array}{l}15.4 \\
23.2\end{array}$ & $\begin{array}{l}+21 \\
+54\end{array}$ & $\begin{array}{l}+3 \cdot 6 \\
+6 \cdot 3\end{array}$ \\
\hline & $\mathrm{P}$ & $\begin{array}{l}16 \cdot 3 \\
16 \cdot 2 \\
26 \cdot 7 \\
30 \cdot 8\end{array}$ & $\begin{array}{r}+35 \\
+61 \\
+102 \\
+120\end{array}$ & $\begin{array}{r}+5.6 \\
+100 \\
+10.0 \\
+10.3\end{array}$ \\
\hline & Mean & - & - & $+7 \cdot 63 \pm r \cdot 16 *$ \\
\hline Abomasum & $\mathbf{F}$ & $\begin{array}{l}13.6 \\
15.0 \\
25.7\end{array}$ & $\begin{array}{r}+8 \\
+15 \\
+19\end{array}$ & $\begin{array}{l}+r \cdot 8 \\
+2 \cdot 9 \\
+2 \cdot I\end{array}$ \\
\hline & $\mathrm{E}$ & $\begin{array}{l}12 \cdot 6 \\
11 \cdot 1 \\
14 \cdot 2\end{array}$ & $\begin{array}{r}-13 \\
-5 \\
+4\end{array}$ & $\begin{array}{l}-2 \cdot 7 \\
-1 \cdot 2 \\
+0.7\end{array}$ \\
\hline & Mean & - & - & $+0.6 \pm 0.92 *$ \\
\hline
\end{tabular}

Table 4. Urinary excretion of the nitrogen and energy of casein supplements given to sheep by infusion into the rumen or abomasum

\begin{tabular}{|c|c|c|c|}
\hline Route of infusion & Sheep & $\begin{array}{l}\text { Increase in } \\
\text { urinary } N \\
\text { as percentage of } \\
\text { casein } N \text { infused }\end{array}$ & $\begin{array}{c}\text { Heat of } \\
\text { combusticn } \\
\text { of urine } \\
(\mathrm{kcal} / \mathrm{g} \mathrm{N})\end{array}$ \\
\hline \multirow[t]{4}{*}{ Rumen } & B & $\begin{array}{l}76 \cdot 7 \\
80 \cdot 3\end{array}$ & $\begin{array}{r}10.9 \\
8.7\end{array}$ \\
\hline & $\mathrm{P}$ & $\begin{array}{l}79 \cdot 6 \\
83 \cdot 8 \\
86 \cdot 6\end{array}$ & $\begin{array}{r}\text { I3.6 } \\
\text { I0.4 } \\
9 \cdot 3\end{array}$ \\
\hline & & $93 \cdot 7$ & $7 \cdot 7$ \\
\hline & Mean & $83 \cdot 4$ & $10.1 \pm 0.84^{*}$ \\
\hline \multirow[t]{3}{*}{ Abomasum } & $\mathrm{F}$ & $\begin{array}{l}78 \cdot 4 \\
75 \cdot 2 \\
85 \cdot 0\end{array}$ & $\begin{array}{l}7 \cdot 9 \\
9 \cdot 7 \\
9 \cdot 3\end{array}$ \\
\hline & E & $\begin{array}{l}97 \cdot 2 \\
94 \cdot 6 \\
87 \cdot 2\end{array}$ & $\begin{array}{l}6.9 \\
5.6 \\
7.5\end{array}$ \\
\hline & Mean & $86 \cdot 3$ & $7 \cdot 8 \pm 0.62 *$ \\
\hline
\end{tabular}

* Standard error of mean. 
urine/g increase in carbon content were, however, the same for both routes of administration. Table 5 presents these findings together with those of Kellner \& Köhler (1905) with oxen and Heim (1956) with sheep.

Composition of the urine. The increases in the excretion of $\mathrm{N}$-containing compounds in urine when casein was given are shown in Table 6. Most of the additional $\mathrm{N}$ was excreted as urea and ammonia in all experiments, but a greater proportion was

Table 5. Additional energy excreted in the urine of sheep and cattle given protein supplements

\section{Animal}

Sheep (Heim, 1956)

Sheep (this paper)

Sheep (this paper)

Oxen (Kellner \& Köhler, I905)

\begin{tabular}{|c|c|c|}
\hline \multirow[b]{2}{*}{ Method of administration } & \multicolumn{2}{|c|}{ Urinary energy } \\
\hline & $\mathrm{kcal} / \mathrm{g}$ carbon & $\mathrm{kcal} / \mathrm{g} \mathrm{N}$ \\
\hline Oral & $1 \mathrm{I} \cdot 8$ & $9 \cdot 8$ \\
\hline Infusion into rumen & $\mathbf{I} \mathbf{I} \cdot \mathbf{I}$ & IO. I \\
\hline Infusion into abomasum & $1 \mathrm{I} \cdot 8$ & $7 \cdot 8$ \\
\hline Oral & II $\cdot 8$ & $6 \cdot 8$ \\
\hline
\end{tabular}

Table 6. Increments in excretion of nitrogen as urea, ammonia, creatine, creatinine, allantoin and hippuric acid by sheep given casein by rumenal or by abomasal infusion

\begin{tabular}{|c|c|c|c|c|c|c|c|c|c|}
\hline \multirow[b]{2}{*}{$\begin{array}{l}\text { Route of } \\
\text { infusion }\end{array}$} & \multirow[b]{2}{*}{ Sheep } & \multirow{2}{*}{$\begin{array}{c}\text { Casein N } \\
\text { infused } \\
(g)\end{array}$} & \multicolumn{7}{|c|}{ Percentage of total urinary $\mathrm{N}$ excreted as } \\
\hline & & & Urea & Ammonia & $\begin{array}{c}\text { Urea }+ \\
\text { ammonia }\end{array}$ & Creatine & Creatinine & Allantoin & $\begin{array}{l}\text { Hippuric } \\
\text { acid }\end{array}$ \\
\hline \multirow[t]{8}{*}{ Rumen } & \multirow[t]{3}{*}{$\mathrm{B}$} & $15 \cdot 4$ & $74 \cdot 3$ & I I 7 & $86 \cdot 0$ & 0.02 & 0.02 & 0.68 & - \\
\hline & & $23 \cdot 2$ & $74^{\cdot} \cdot 1$ & 0.4 & $74 \cdot 5$ & $-0 \cdot 16$ & 0.46 & $2 \cdot 11$ & - \\
\hline & & Mean & $74 \cdot 2$ & $6 \cdot 0$ & $80 \cdot 2$ & -0.07 & 0.24 & $1 \cdot 39$ & - \\
\hline & \multirow[t]{5}{*}{$\mathrm{P}$} & $16 \cdot 3$ & $82 \cdot 5$ & $4 \cdot 6$ & $87 \cdot 1$ & 0.65 & -0.26 & 0.85 & $4 \cdot 60$ \\
\hline & & $16 \cdot 2$ & $82 \cdot 4$ & II 4 & $93 \cdot 8$ & 0.58 & -0.07 & $2 \cdot 74$ & 4.24 \\
\hline & & $26 \cdot 7$ & $80 \cdot 8$ & $9 \cdot 6$ & 90.4 & 0.31 & 0.12 & $2 \cdot 5^{\circ}$ & $4 \cdot 42$ \\
\hline & & $30 \cdot 8$ & $73 \cdot 6$ & $11 \cdot 2$ & $84 \cdot 8$ & 0.36 & $-O \cdot I I$ & I. 44 & $2 \cdot 77$ \\
\hline & & Mean & $79 \cdot 8$ & $9 \cdot 2$ & 89.0 & 0.47 & -0.08 & $\mathbf{r} \cdot 88$ & 4.01 \\
\hline \multirow[t]{8}{*}{ Abomasum } & \multirow[t]{4}{*}{$\mathrm{F}$} & $13 \cdot 6$ & $92 \cdot 5$ & -0.8 & $9 r \cdot 7$ & 0.14 & 0.33 & 0.06 & - \\
\hline & & 15.0 & 90.8 & $-2 \cdot 3$ & $88 \cdot 5$ & 0.36 & 0.74 & $I \cdot 23$ & - \\
\hline & & $25 \cdot 7$ & $90 \cdot 1$ & 0.3 & 90.4 & 0.01 & 0.68 & 0.54 & - \\
\hline & & Mean & $9 \mathrm{I} \cdot \mathrm{I}$ & -0.9 & $90 \cdot 2$ & 0.17 & 0.58 & 0.61 & - \\
\hline & \multirow[t]{4}{*}{$\mathbf{E}$} & $12 \cdot 6$ & $91 \cdot 8$ & 0.2 & $92 \cdot 0$ & -0.20 & 0.86 & 0.93 & $I \cdot I 6$ \\
\hline & & II'I & $88 \cdot 6$ & $4 \cdot I$ & $92 \cdot 7$ & -0.24 & $1 \cdot 33$ & $\mathrm{x} \cdot \mathrm{r} 3$ & 0.65 \\
\hline & & $\mathrm{I} 4 \cdot 2$ & $6 I \cdot 2$ & $10 \cdot 3$ & $7 I \cdot 5$ & -0.07 & 0.63 & $2 \cdot 02$ & $4 \cdot 15$ \\
\hline & & Mean & $80 \cdot 5$ & $4^{\circ} 9$ & $85 \cdot 4$ & -0.17 & 0.94 & $x \cdot 36$ & $1 \cdot 99$ \\
\hline Rumen & & Mean & $78 \cdot 0$ & $8 \cdot 1$ & $86 \cdot 1$ & 0.29 & 0.03 & $1 \cdot 72$ & $4 \cdot 01$ \\
\hline Abomasum & & Mean & 85.9 & I.9 & $87 \cdot 8$ & 0.00 & 0.76 & 0.98 & $1 \cdot 99$ \\
\hline
\end{tabular}

The values are the increments in the excretion of the compounds which occurred when casein was infused. They are expressed as percentages of the corresponding increments in total $\mathrm{N}$ excreted.

excreted as ammonia by the sheep given casein by rumen infusion. This finding suggests a difference in metabolism associated with bacterial fermentation in the rumen, but the possibility of formation of ammonia from urea after the urine had been excreted cannot, however, be excluded. There was an indication that more allantoin $\mathrm{N}$ and more hippuric acid $\mathrm{N}$ was excreted when the casein was infused into 
the rumen. This would be consistent with bacterial fermentation of the casein and would account for the higher calorific value/g $\mathrm{N}$ of urine from sheep given casein by rumen infusion. The amounts of $\mathrm{N}$ involved were, however, small. The recovery of the $\mathrm{N}$ infused in terms of known compounds containing $\mathrm{N}$ was $92 \cdot \mathrm{I} \%$ for sheep given casein by rumen infusion and $9 \mathrm{I} \cdot 5 \%$ for sheep given it by abomasal infusion.

Metabolizable energy. The lower digestibility of casein given by rumen infusion, the larger amounts of methane produced and the higher calorific value of the urine $/ \mathrm{g} N$ excreted all point to a lower metabolizable energy value of casein when given by infusion into the rumen compared with infusion into the abomasum. The individual results are given in Table 7. The metabolizable energy as a percentage of the energy of the casein was $62 \cdot 5$ when casein was given by rumen infusion and $87 \cdot 3$ when given by abomasal infusion.

Table 7. Energy retention of sheep given casein supplements by infusion into the rumen or abomasum

\begin{tabular}{|c|c|c|c|c|c|c|c|}
\hline \multirow[b]{2}{*}{$\begin{array}{l}\text { Route of } \\
\text { infusion }\end{array}$} & \multirow[b]{2}{*}{ Sheep } & \multirow[b]{2}{*}{$\begin{array}{c}\text { Energy } \\
\text { content of } \\
\text { casein given } \\
\text { (kcal/day) }\end{array}$} & \multirow[b]{2}{*}{$\begin{array}{c}\text { Metabolizable } \\
\text { energy of } \\
\text { casein } \\
\text { (kcal/day) }\end{array}$} & \multicolumn{3}{|c|}{ Energy retention (kcal/day) } & \multirow{2}{*}{$\begin{array}{c}\text { Net } \\
\text { availability } \\
\text { of } \\
\text { metabolizable } \\
\text { energy } \\
(\%)\end{array}$} \\
\hline & & & & $\begin{array}{c}\text { RQ } \\
\text { method }\end{array}$ & $\begin{array}{l}\mathrm{C} \text { and } \mathrm{N} \\
\text { retention } \\
\text { method }\end{array}$ & Mean & \\
\hline \multirow[t]{2}{*}{ Rumen } & $\mathrm{B}$ & $572 \cdot 7$ & $287 \cdot 8$ & 150.4 & I I I . 6 & I 3 I'O & $\begin{array}{l}45 \cdot 5 \\
57 \cdot 7\end{array}$ \\
\hline & $\mathbf{P}$ & $\begin{array}{r}617 \cdot 5 \\
609 \cdot 5 \\
\text { I010.6 } \\
\text { I } 62 \cdot 8\end{array}$ & $\begin{array}{l}539 \cdot 1 \\
384 \cdot 0 \\
373 \cdot 2 \\
738 \cdot 2 \\
727 \cdot 7\end{array}$ & $\begin{array}{l}325 \cdot 2 \\
207 \cdot 7 \\
203 \cdot 2 \\
436 \cdot 7 \\
335 \cdot 2\end{array}$ & $\begin{array}{l}290 \cdot 7 \\
253 \cdot 5 \\
226 \cdot 0 \\
230 \cdot 1 \\
181 \cdot 8\end{array}$ & $\begin{array}{l}310 \cdot 9 \\
230 \cdot 6 \\
214 \cdot 6 \\
333 \cdot 4 \\
258 \cdot 5\end{array}$ & $\begin{array}{l}57 \cdot 7 \\
60 \cdot 0 \\
57 \cdot 5 \\
45 \cdot 2 \\
35 \cdot 5\end{array}$ \\
\hline \multirow[t]{2}{*}{ Abomasum } & $\mathbf{F}$ & $\begin{array}{l}506 \cdot 1 \\
558 \cdot 2 \\
954 \cdot 2\end{array}$ & $\begin{array}{l}395 \cdot 3 \\
520 \cdot 2 \\
784 \cdot 3\end{array}$ & $\begin{array}{l}225 \cdot 5 \\
344 \cdot 8 \\
418 \cdot 8\end{array}$ & $\begin{array}{l}242 \cdot 7 \\
391 \cdot 2 \\
463 \cdot 4\end{array}$ & $\begin{array}{l}234 \cdot 1 \\
368 \cdot 0 \\
44 I \cdot I\end{array}$ & $\begin{array}{l}59 \cdot 2 \\
70 \cdot 7 \\
56 \cdot 2\end{array}$ \\
\hline & $\mathbf{E}$ & $\begin{array}{l}481 \cdot 3 \\
422 \cdot 8 \\
540 \cdot 2\end{array}$ & $\begin{array}{l}397 \cdot 3 \\
436 \cdot I \\
458 \cdot 6\end{array}$ & $\begin{array}{l}250 \cdot 5 \\
358 \cdot 7 \\
262 \cdot 5\end{array}$ & $\begin{array}{l}283 \cdot 1 \\
214 \cdot 8 \\
371 \cdot 3\end{array}$ & $\begin{array}{l}266 \cdot 8 \\
286 \cdot 8 \\
316 \cdot 9\end{array}$ & $\begin{array}{l}67 \cdot 2 \\
65 \cdot 8 \\
69 \cdot 1\end{array}$ \\
\hline
\end{tabular}

Energy retention. Energy retention was estimated in two ways, first from the heat of combustion of the excreta and methane and the heat production determined from oxygen consumption and the non-protein respiratory quotient, and secondly from simultaneous determinations of the retention of $\mathrm{C}$ and $\mathrm{N}$ in the body, the factors of Blaxter \& Rook (1953) being used. The increases in energy retention which occurred when casein was infused, determined in both ways, are given in Table 7. The mean values are plotted in Fig. I against the calorific value of the casein infused, and it is clear that the energy of casein given by abomasal infusion was used more efficiently than that of casein given by infusion into the rumen.

Part of this difference was due to the lower proportion of the energy of the casein that was metabolizable, and in Fig. 2 the energy retained from casein is plotted against the metabolizable energy of the supplements. The results indicate that the metabolizable energy of casein given by abomasal infusion was more efficiently used to promote synthesis of energy-containing materials in the body than was the meta- 
bolizable energy of casein given by infusion into the rumen. The difference was not so marked as when the comparison was made in terms of the heat of combustion of the casein infused.

Analysis of variance of the net availabilities of the metabolizable energy of the casein

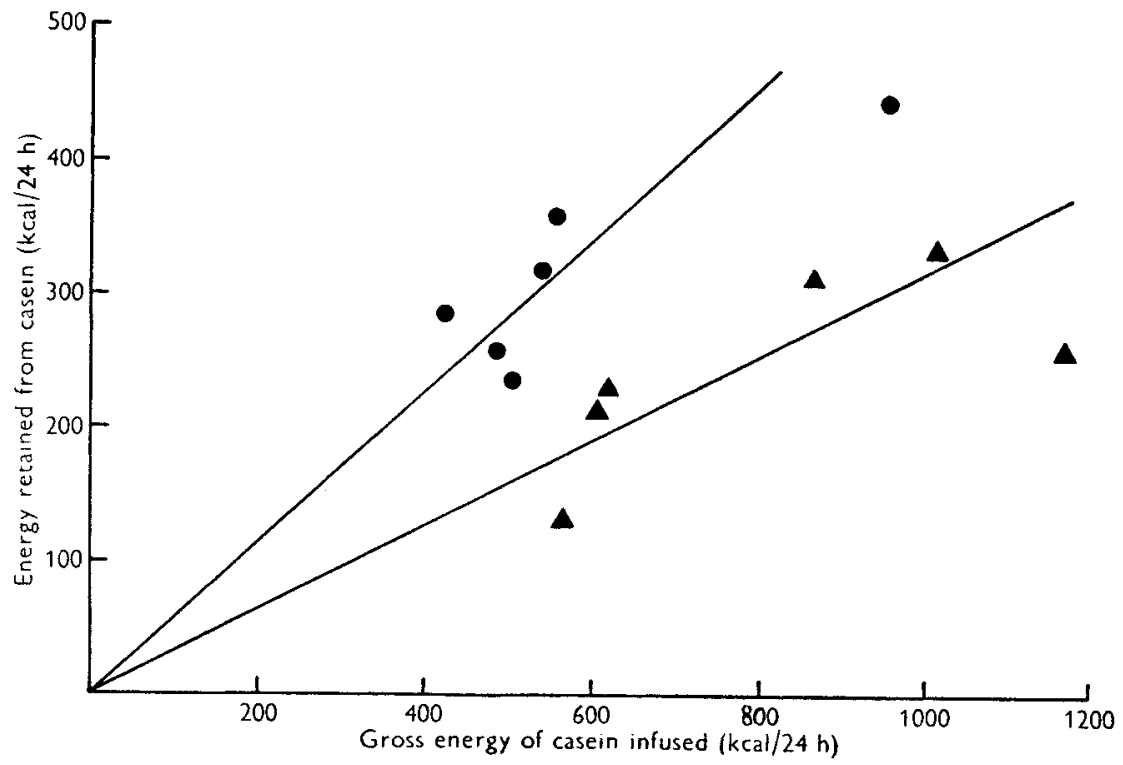

Fig. I. Retention by fattening sheep of the gross energy of casein infused into the abomasum, $\bullet$, or into the rumen, $\Delta$.

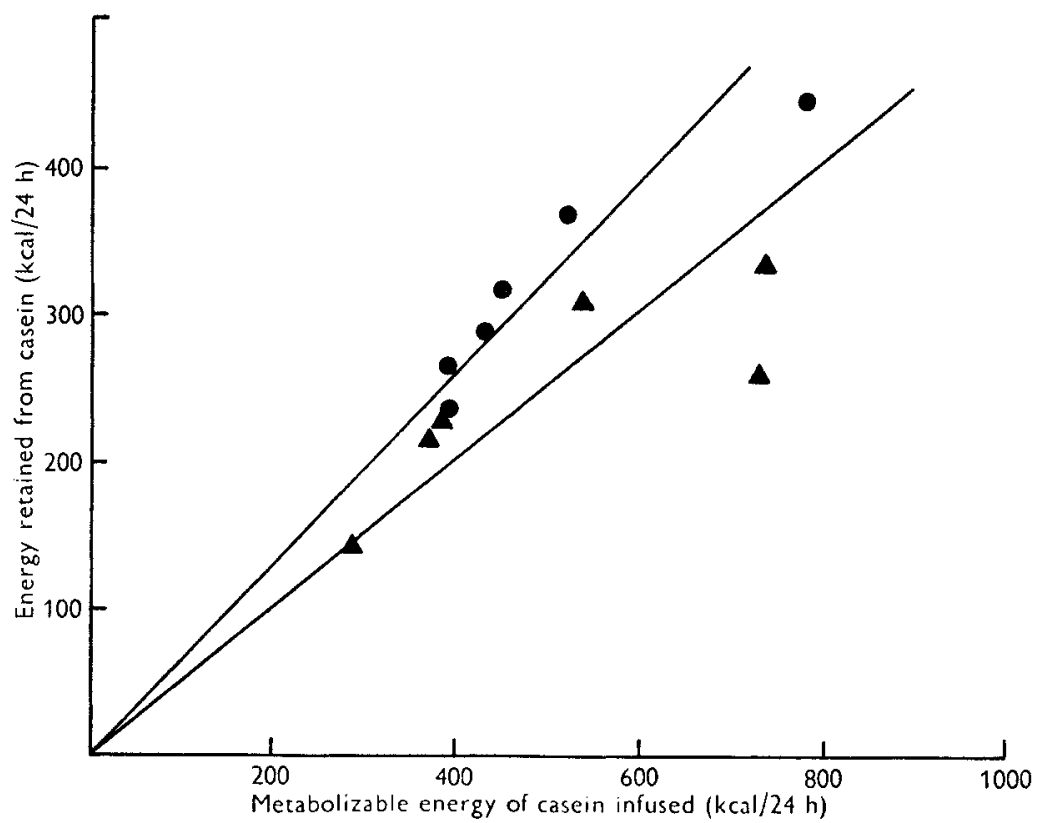

Fig. 2. Retention by fattening sheep of the metabolizable energy of casein infused into the abomasum, $\bullet$, or into the rumen, $\wedge$. 
showed that, whether the test of significance was based on between-animal variation or within-animal variation, the difference in utilization of the casein by the two routes was significant $(0.05>P>0.01)$. The mean values were $50.2 \pm 3.2$ and $64.7 \pm$ $3.2 \mathrm{kcal}$ net energy $/ 100 \mathrm{kcal}$ metabolizable energy, the errors representing the pooled within- and between-animal variations.

Increases in the retention of the $\mathrm{N}$ by the sheep occurred when casein was given by either route, and the mean daily amount retained was $10.1 \%$ of the $\mathrm{N}$ of the casein given for the sheep receiving casein by rumen infusion and $16.2 \%$ for those given it by infusion into the abomasum. On the assumption that the whole of the $\mathrm{N}$ was retained as protein, it accounted for between 20 and $29 \%$ of the total energy retained when infused into the rumen and abomasum respectively. The retention of $20-30 \%$ of the energy of supplementary food as protein and conversely $70-80 \%$ as fat by adult sheep is similar to the results obtained when volatile fatty acids were given as a supplementary source of energy to sheep (Armstrong, Blaxter, Graham \& Wainman, 1958).

\section{DISCUSSION}

It was shown by Chalmers, Cuthbertson \& Synge (1954) that when sheep subsisting on low-protein diets were given casein by duodenal infusion they retained more $\mathrm{N}$ and excreted less $\mathrm{N}$ in the urine than when they were given casein by rumen infusion. In their experiments, the value of casein as a source of amino acids was measured. In the experiments reported here the value of casein as an energy source for synthesis of body fat was considered by ensuring that an excess of $\mathrm{N}$ was supplied by the basal ration. The results in Table $\mathrm{I}$ show that this condition was met.

The results obtained when casein was infused into the rumen may be compared with those found in the two sets of experiments in which ruminants have been given protein supplements by mouth. Our results show that the apparent digestibility of casein given by slow infusion into the rumen was $90 \%$. This value is in agreement with that of $86 \%$ found by Keller \& Köhler (1905) with steers given wheat gluten, and that of $93.5 \%$ found by Heim (1956) with sheep given a mixture of casein, egg albumen and wheat gluten. The loss of energy as methane on infusion of casein, amounting to $7.6 \mathrm{kcal} / \mathrm{I00} \mathrm{kcal}$ casein, was higher than the values of $1 \cdot 5-5.3 \mathrm{kcal} /$ Ioo kcal protein found in Heim's experiments. Kellner \& Köhler stated that their protein supplement had no effect on methane production. The loss of energy in urine as shown in Table 5 was very much the same in our experiments as in Heim's. The values observed with cattle by Kellner \& Köhler seem to be rather low. The net availability of metabolizable energy was $50.2 \pm 3 \cdot 2$ in our experiments, $47 \cdot 6$ in Kellner $\&$ Köhler's and $45^{\circ} 9$ in Heim's. This last value is that given by Crasemann (r954) who recomputed the data Heim had obtained in the Zürich laboratory. The results from all three sets of experiments are thus in good agreement with respect to the estimate they provide of the net availability of the energy of protein. Similarly, the estimates of the total energy retained/100 kcal of supplementary protein given were $3^{1 \cdot} \pm 3.6$ in our experiments, 33.4 in Kellner \& Köhler's and 34.5 in Heim's.

The results obtained when casein was infused into the abomasum differ very 
markedly from these. The protein was completely digested, no methane was produced and the loss of energy in urine was smaller than it was when casein was infused into the rumen. The net availability of metabolizable energy was $64 \cdot 7 \pm 3^{\cdot 2}$, and the energy retained/roo kcal protein given was $56 \cdot 7 \pm 3.6 \mathrm{kcal}$. The latter is $80 \%$ greater than when the same protein was given by infusion into the rumen. These results with abomasal infusions are similar to those obtained in simple-stomached animals. Thus in pigs the energy retained when wheat gluten was given was found by Fingerling et al. (1912-13) to be $57^{\cdot 2} \mathrm{kcal} / \mathrm{roo} \mathrm{kcal}$ protein, and with rats Kriss $e$ t al. (1934) found $54.9 \mathrm{kcal}$ retained/100 kcal casein given.

The results of our experiments suggest very strongly that the lower nutritive value of protein as an energy source for lipogenesis in ruminants compared with nonruminants is the result of fermentative changes involving protein which occur in the rumen. They are not due to a difference between these two classes of animal in their ability to obtain free energy by dissimilation of the amino acids which they absorb. The lower apparent digestibility of the casein given by infusion into the rumen compared with that given by abomasal infusion, can be explained by an increase in bacterial growth in the rumen after infusion of soluble protein supplements and by an incomplete hydrolysis of the $\mathrm{N}$-containing compounds of bacteria in parts of the gut distal to the rumen. From the increase in allantoin and hippurate excretion when casein was given by rumen infusion, it can be inferred that some bacterial hydrolysis occurred. Such inferences are in accord with many observations that soluble proteins such as casein when given to ruminants are largely hydrolysed in the rumen and from a proportion of the products of hydrolysis bacterial protein is synthesized, to be digested lower in the tract. This aspect has been reviewed by Annison \& Lewis (1959) and by Chalmers (196r).

\section{SUMMARY}

I. The utilization of the energy of casein when given to sheep by infusion into the rumen has been compared with its utilization when given by infusion into the abomasum.

2. Four sheep, two fitted with abomasal cannulas and two with rumenal cannulas, were given a constant ration of dried grass sufficient to maintain them in positive energy and nitrogen balance. Energy metabolism was measured during periods when saline was infused into the rumen or abomasum and during periods when a casein solution was infused.

3. The net energy of casein for fat production ( $\mathrm{kcal} / \mathrm{I}$ oo kcal given) was $3 \mathbf{I}^{\cdot} \mathrm{I} \pm 3 \cdot 6$ after infusion into the rumen and $5^{\circ} 7 \pm 3^{\circ} 6$ after abomasal infusion.

4. When infused into the rumen casein had a lower digestibility and caused a greater loss of energy as $\mathrm{CH}_{4}$ and in urine than when it was infused into the abomasum.

5. The net availability of the metabolizable energy of casein was $50 \cdot 2 \pm 3^{\cdot 2}$ when given by rumenal infusion and $64 \cdot 7 \pm 3 \cdot 2$ when given by abomasal infusion.

6. Slightly more of the casein $\mathrm{N}$ was excreted in the urine as allantoin and hippuric acid after infusion into the rumen than after abomasal infusion. The difference was not statistically significant. 
7. The results obtained are compared with those observed in simple-stomached animals and ruminants given protein by mouth, and the effect of fermentation of protein in the rumen on the utilization of casein energy is discussed. It is concluded that the low utilization of the energy of protein by ruminants can be explained by the fermentation processes in the rumen.

\section{REFERENCES}

Annison, E. F. \& Lewis, D. (1959). Metabolism in the Rumen, p. 104. London: Methuen.

Armstrong, D. G. \& Blaxter, K. L. (1957). Brit. F. Nutr. II, 247.

Armstrong, D. G., Blaxter, K. L., Graham, N. McC. \& Wainman, F. W. (1958). Brit. F. Nutr. $12,177$. Blaxter, K. L. \& Rook, J. A. F. (1953). Brit. F. Nutr. 7, 83.

Bonsnes, R. W. \& Taussky, H. H. (1945). F. biol. Chem. 158, $58 \mathrm{I}$.

Chalmers, M. I. (1961). In Digestive Physiology and Nutrition of the Ruminant, p. 205. [D. Lewis, editor.] London: Butterworths.

Chalmers, M. I., Cuthbertson, D. P. \& Synge, R. L. M. (1954). F. agric. Sci. 44, 254.

Conway, E. J. (1947). Microdiffusion Analysis and Volumetric Error, 2nd ed., p. ro6. London: Crosby Lockwood and Sons Ltd.

Crasemann, E. (1954). In Festschrift anlässlich des 100 jährigen Bestehens der Landwirtschaftlichen Versuchsstation Leipzig-Möckern. Vol. 2. Ioo Fahre Möckern. Die Bewertung der Futterstoffe und andere Probleme der Tierernährung, p. I4I. [K. Nehring, editor.] Berlin: Deutscher Bauernverlag.

Fingerling, G., Köhler, A. \& Reinhardt, F. R. (I9г2-13). Landw. VersSta. 84, I 49.

Graham, N. McC., Armstrong, D. G. \& Blaxter, K. L. (r958). E.A.A.P. Publ. no. 8, p. I57.

Hampton, J. W. F. (1948). S. Afr. F. med. Sci. r3, 45.

Heim, G. (1956). Die Stoffliche und energetische Wirkung einer Eiweisszulage sowie einer Zulage, bestehend aus Stärke, Fett und Eiweiss beim ausgewachsenen Schafe. Thesis, Eidgenössische Technische Hochschule, Zürich.

Kellner, O. \& Köhler, A. (I905). Landw. VersSta. 53, г.

Kriss, M., Forbes, E. B. \& Miller, R. C. (1934). F. Nutr. 8, $5 \circ 9$.

Martin, A. K. \& Blaxter, K. L. (r96r). Proc. Nutr. Soc. 2o, vii.

Van Slyke, D. D. \& Cullen, G. E. (1914). F. biol. Chem. 19, 2 I.

Wainman, F. W. \& Blaxter, K. L. (1958). E.A.A.P. Publ. no. 8, p. 8o.

Young, E. G. \& Conway, C. F. (1942). F. biol. Chem. 142, 839. 